\title{
Lateral transport of sediment particles in the Okinawa Trough determined by natural radionuclides
}

\author{
Hisashi Narita, KoH Harada and Shizuo Tsunogai \\ Department of Chemistry, Faculty of Fisheries, Hokkaido University, Hakodate 041, Japan
}

(Received January 9, 1990; Accepted May 4, 1990)

\begin{abstract}
Settling particles at $640 \mathrm{~m}, 1390 \mathrm{~m}$, and $1920 \mathrm{~m}$ depths in the Okinawa Trough and bottom sediments at six sites in the East China Sea were analyzed for $U$ and Th isotopes, ${ }^{210} \mathrm{~Pb}$, and ${ }^{210} \mathrm{Po}$. Concentrations of ${ }^{232} \mathrm{Th}$ in the settling particles were higher than those observed in the open ocean and were relatively constant with depth compared with other radiogenic nuclides. Fluxes and concentrations of these radiogenic nuclides increased with depth and the measured fluxes were larger than those calculated from water column inventories. While sinking through the water column of 640-1390 m, the increases in ${ }^{210} \mathrm{~Pb}$ and unsupported ${ }^{228} \mathrm{Th}$ fluxes originating intensively in the shelf region were much larger than the unsupported ${ }^{230} \mathrm{Th}$ fluxes produced evenly in sea water. The ${ }^{210} \mathrm{Po} /{ }^{210} \mathrm{~Pb}$ activity ratio in the settling particles was almost unity and the ${ }^{228} \mathrm{Th} /{ }^{230} \mathrm{Th}$ activity ratio of the radiogenic fraction was much smaller than the ratio of the production rates of these nuclides in the shelf water. These results suggest that a large fraction of the deeper settling particles, as well as the sediments in the trough zone originating in the continental shelf zone, are transported laterally and downward via the near bottom layer on a time scale of approximately 16 years on the average.
\end{abstract}

\section{INTRODUCTION}

Recently, much attention has been focused on the lateral transport of chemical species in the ocean. In the studies of the lateral transport of chemical elements taken up or released during their movement, the U/Th series of isotopes produced from their parents seems to be useful. The radioisotopes of elements, which are produced from their dissolved parents and have short residence times, show deficiencies in their radioactivities due to their removal by settling particles (Moore and Sackett, 1964; Nozaki et al., 1981; Minagawa and Tsunogai, 1980; Matsumoto, 1975; Rama et al., 1961; Tsunogai and Nozaki, 1971; Craig et al., 1973; Li et al., 1980; etc.). The examples are the pairs of ${ }^{238} \mathrm{U}-{ }^{234} \mathrm{Th}, \quad{ }^{234} \mathrm{U}-{ }^{230} \mathrm{Th}, \quad{ }^{235} \mathrm{U}-{ }^{231} \mathrm{~Pa}$, ${ }^{226} \mathrm{Ra}-{ }^{210} \mathrm{~Pb},{ }^{210} \mathrm{~Pb}-{ }^{210} \mathrm{Po}$, and ${ }^{228} \mathrm{Ra}-{ }^{228} \mathrm{Th}$, which provide time scales for the removal processes according to their half-lives.

Bacon et al. (1976) have found a pronounced
${ }^{210} \mathrm{~Pb} /{ }^{226} \mathrm{R}$ a disequilibrium in the Atlantic Ocean and concluded that the removal of ${ }^{210} \mathrm{~Pb}$ is caused by scavenging at the sediment-water interface. Turekian (1977) and Nozaki et al. (1976) have claimed that particles have an important role in the removal of reactive elements. Anderson et al. $(1983 \mathrm{a}, \mathrm{b})$ have suggested that ${ }^{231} \mathrm{~Pa}$ relative to ${ }^{230} \mathrm{Th}$ is transported laterally from the open ocean to ocean margins and removed by settling particles. Taguchi et al. (1989) have also suggested that ${ }^{231} \mathrm{~Pa}$ transported from oligotrophic regions is effectively removed in biologically productive seas, which is compatible to the distribution of the ${ }^{230} \mathrm{Th} /{ }^{231} \mathrm{~Pa}$ ratio in the surface sediments in the Pacific Ocean mapped by Yang et al. (1986).

Brewer et al. (1980) and Tsunogai et al. (1982) have found from sediment-trap experiments that the vertical fluxes of $\mathrm{Al}$ increase with depth down to the bottom sediments. They have also reported that the $\mathrm{Mn} / \mathrm{Al}$ ratio in the settling particles increases with depth. Since 
manganese is known to be supplied from anoxic coastal and hemipelagic sediments (e.g., Tsunogai and Kusakabe, 1982), Tsunogai and Noriki (1987) have presumed that the manganese is incorporated into fine particles after it is oxidized and transported to the pelagic ocean by the lateral movement of sea water.

Since the coastal areas have high biological productivity, the transport process of biogenic and non-biogenic particles from the coastal zone to the pelagic zone is one of the major problems in oceanography. The Shelf Edge Exchange Processes (SEEP) program was organized by U.S. scientists to solve the problems (Walsh et al., 1988). Biscaye et al. (1988) found that particles are transported from the continental shelf to the open ocean by observing the fluxes of ${ }^{210} \mathrm{~Pb}$, organic carbon, and calcium carbonate using sediment traps along the SEEP-I traverse.

To confirm this evidence, we carried out a sediment-trap experiment in the Okinawa
Trough together with the sampling of bottom sediments from the continental-shelf zone to the trough. This paper will discuss the lateral transport of particles by using natural radionuclides.

\section{SAMPling AND Methods}

Settling particles and sediment samples were collected in the Okinawa Trough and the East China Sea during the 1987 Corona Borealis Expedition on the R/V Hakuho-Maru (Fig. 1).

Sediment traps were deployed at Station CB 7 in the Okinawa Trough on 14 May and retrieved on 26 May 1987. The settling particle samples were collected at three depths, $640 \mathrm{~m}, 1390 \mathrm{~m}$, and $1920 \mathrm{~m}$, with the D type traps (Tsunogai et al., 1986) consisting of twin cylindrical cones each with four cups working in time series. Upon recovery, the settling particles were transferred onto a pre-weighed Nuclepore filter $(0.6 \mu \mathrm{m})$.

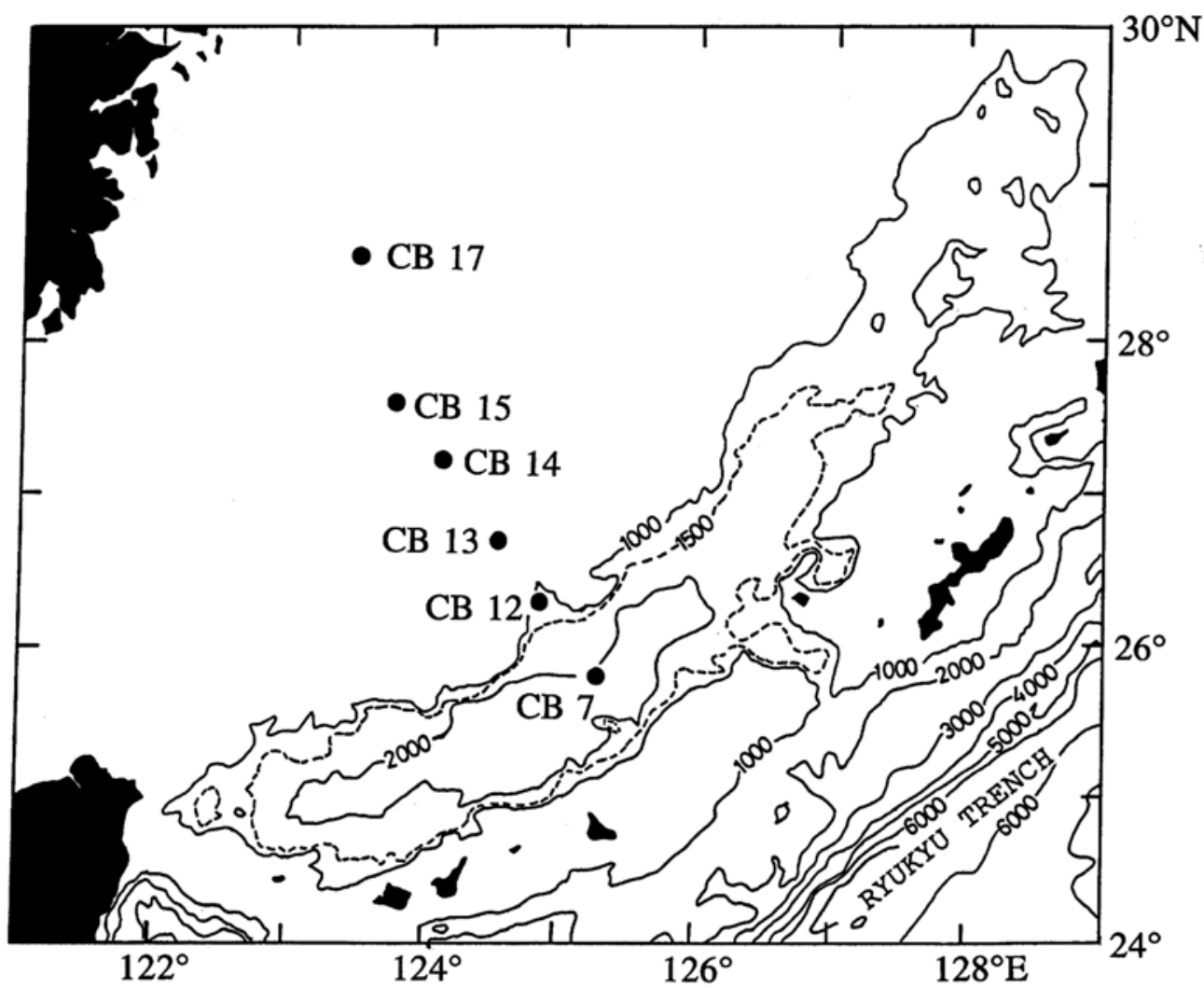

Fig. 1. Location of sampling sites. 
Their dry weights were measured by the method of Uemastu et al. (1978). In this study, preservatives were not used because the sampling period was short. The concentrations of phosphate in the supernatant solutions in the cups were not significantly different from the ambient sea water (Noriki, personal communication). The four time-series samples for one cylinder at each depth were put together and used to determine of the radioactivities of $U, T h$, $\mathrm{Pb}$, and $\mathrm{Po}$. The other samples were used to determine the major elements and other trace elements.

The sediment samples were collected at Stations CB 13, CB 14, CB 15, and CB 17 in the continental shelf zone, Station $\mathrm{CB} 12$ in the slope, and Station CB 7-2 in the Okinawa Trough with a box corer or a grab sampler. The core samples were cut into segments of one or two cm on shipboard. These core samples and the surface sediments were radiochemically analyzed for $\mathrm{U}$, $\mathrm{Th}$, and $\mathrm{Pb}$.

Dried samples of $60-300 \mathrm{mg}$ for the settling particles or 1-3 g for surface sediments were taken for the analysis. These samples were completely dissolved with a mixture of $\mathrm{HNO}_{3}, \mathrm{HF}$, and $\mathrm{HClO}_{4}$ in a Teflon bomb for the settling particle samples and in a Teflon beaker for the sediment samples. To determine the accumulation rate of ${ }^{210} \mathrm{~Pb}$ in the bottom sediment, dried samples of 5-10 $\mathrm{g}$ each were taken and leached with an almost boiling solution of $6 \mathrm{M} \mathrm{HCl}$ (Aller and Cochran, 1976) for 4 hours after heating at $450^{\circ} \mathrm{C}$. Their natural radionuclides were analyzed by the methods of Harada and Tsunogai (1985) and Tsunogai and Yamada (1980). Their activities were measured by an $\alpha$ spectrometer and a low-background $2 \pi$ gas-flow GM counter.

\section{Results AND Discussion}

The concentration of ${ }^{232} \mathrm{Th}$ in the settling particles

The total mass flux (Table 1) increased with depth in the Okinawa Trough. The observed fluxes at $1390 \mathrm{~m}$ and $1920 \mathrm{~m}$ were 10 times or more larger than those observed in the central Pacific (Honjo et al., 1982; Noriki and Tsunogai, 1986).

The concentrations of ${ }^{232} \mathrm{Th}$ of land origin in the settling particles ranged from 1.8 to 2.1 $\mathrm{dpm} / \mathrm{g}$, which were a few to a few tens times greater than those reported in the usual open ocean (Anderson et al., 1983a, Taguchi et al., 1989). The vertical variation of its concentration was smaller than those of other radiogenic nuclides studied here. The concentrations of ${ }^{232} \mathrm{Th}$ were approximately $60 \%$ of its concentration in the surface sediment at Station CB 7-2 (Table 3). Since about $90 \%$ of the sediment is lithogenic material (Saito, personal communication), about half of the settling particles consists of lithogenic material. The lithogenic fraction in the settling particles is relatively constant with depth.

The lateral transport of ${ }^{210} \mathrm{~Pb}$-bearing particles from the continental shelf

Both the observed concentrations (Table 1) and fluxes (Fig. 2) of ${ }^{210} \mathrm{~Pb}$ increased during their settling through the water column. The flux of ${ }^{210} \mathrm{~Pb}$ increased 10 times while sinking through the water column from 640 to $1390 \mathrm{~m}$. This in-

Table 1. Concentrations of radionuclides in the settling particles, at $C B 7\left(25^{\circ} 47^{\prime} \mathrm{N}, 125^{\circ} 22^{\prime} \mathrm{E}, 1920 \mathrm{~m}\right)$

\begin{tabular}{cccccccc}
\hline \multirow{2}{*}{$\begin{array}{c}\text { Depth } \\
(\mathrm{m})\end{array}$} & $\begin{array}{c}\text { Total mass flux } \\
\left(\mathrm{mg} / \mathrm{cm}^{2} / \mathrm{yr}\right)\end{array}$ & \multicolumn{5}{c}{ Concentration $(\mathrm{dpm} / \mathrm{g})$} \\
\cline { 3 - 7 } & & ${ }^{238} \mathrm{U}$ & ${ }^{232} \mathrm{Th}$ & ${ }^{230} \mathrm{Th}$ & ${ }^{228} \mathrm{Th}$ & ${ }^{210} \mathrm{~Pb}$ & ${ }^{210} \mathrm{Po}$ \\
\hline 640 & 1.52 & $1.89 \pm 0.09$ & $1.78 \pm 0.06$ & $1.60 \pm 0.06$ & $10.3 \pm 0.2$ & $126 \pm 7$ & $132 \pm 1$ \\
1390 & 5.83 & $1.59 \pm 0.06$ & $2.06 \pm 0.04$ & $1.99 \pm 0.04$ & $18.9 \pm 0.2$ & $325 \pm 7$ & $314 \pm 2$ \\
1920 & 6.75 & $1.60 \pm 0.06$ & $2.06 \pm 0.04$ & $2.43 \pm 0.04$ & $21.6 \pm 0.2$ & $441 \pm 12$ & $437 \pm 6$ \\
\hline
\end{tabular}

All errors are of $1 \sigma$ counting statistics. 
$\mathrm{Pb}-210$ flux (dpm/cm²/yr)

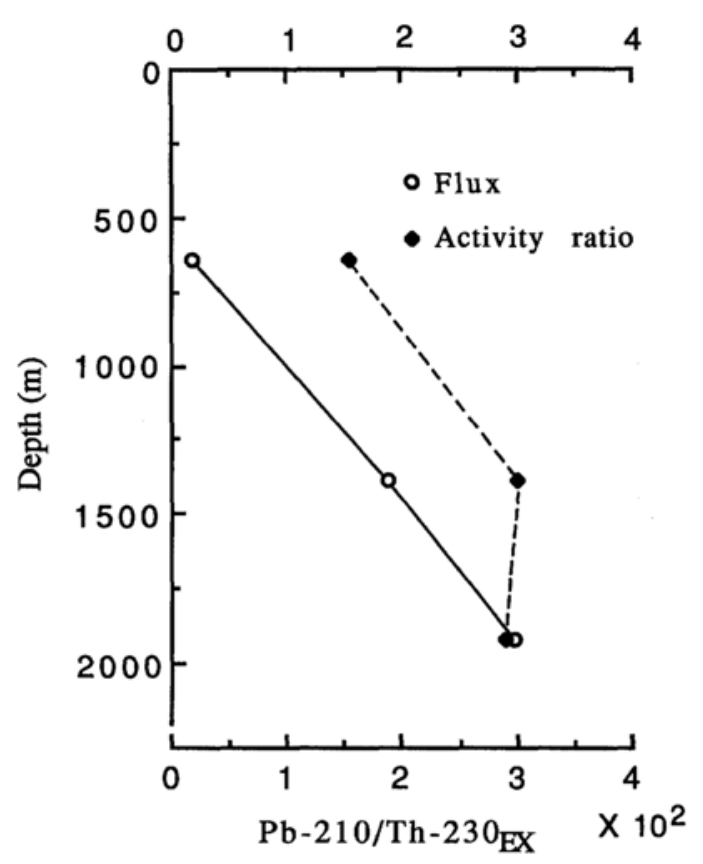

Fig. 2. Particulate fluxes of ${ }^{210} \mathrm{~Pb}$ and activity ratios of ${ }^{210} \mathrm{~Pb} /{ }^{230} \mathrm{Th} \mathrm{EX}_{\mathrm{X}}$ observed with sediment traps in the Okinawa Trough.

crease was much larger than that in the ${ }^{230} \mathrm{Th}_{\mathrm{EX}}$ flux, which is a fraction of the flux of ${ }^{230} \mathrm{Th}$ produced only from the radioactive decay of ${ }^{234} \mathrm{U}$ in sea water (Fig. 2). The ${ }^{210} \mathrm{~Pb}$ fluxes observed at 1390 and $1920 \mathrm{~m}$ were 3-8 times larger than those observed at the same depths in the biologically productive northern North Pacific and Antarctic Oceans where ${ }^{210} \mathrm{~Pb}$ and other metals are actively removed by settling particles (Tsunogai et al., 1982, Harada and Tsunogai, 1986a).

The flux of ${ }^{210} \mathrm{~Pb}$ at $640 \mathrm{~m}$ depth was only $10 \%$ of its deposition rate from the atmosphere observed at Naha City on Okinawa Island, 1.6 $\mathrm{dpm} / \mathrm{cm}^{2} / \mathrm{yr}$ (Tsunogai et al., 1985). Although we do not know the exact trapping efficiency, this small flux at $640 \mathrm{~m}$ depth can not be considered to be due to the low trapping efficiency for the following reasons. There was no significant difference between the two sets of total mass flux data obtained from our time-series type sediment trap consisting of twin collectors. We ob-
$\mathrm{Pb}-210 \mathrm{ex} \quad(\mathrm{dpm} / \mathrm{g})$

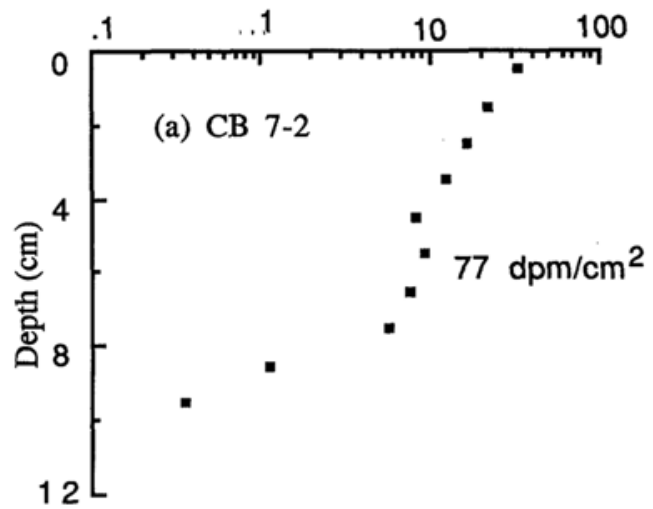

$\mathrm{Pb}-210 \mathrm{ex} \quad(\mathrm{dpm} / \mathrm{g})$

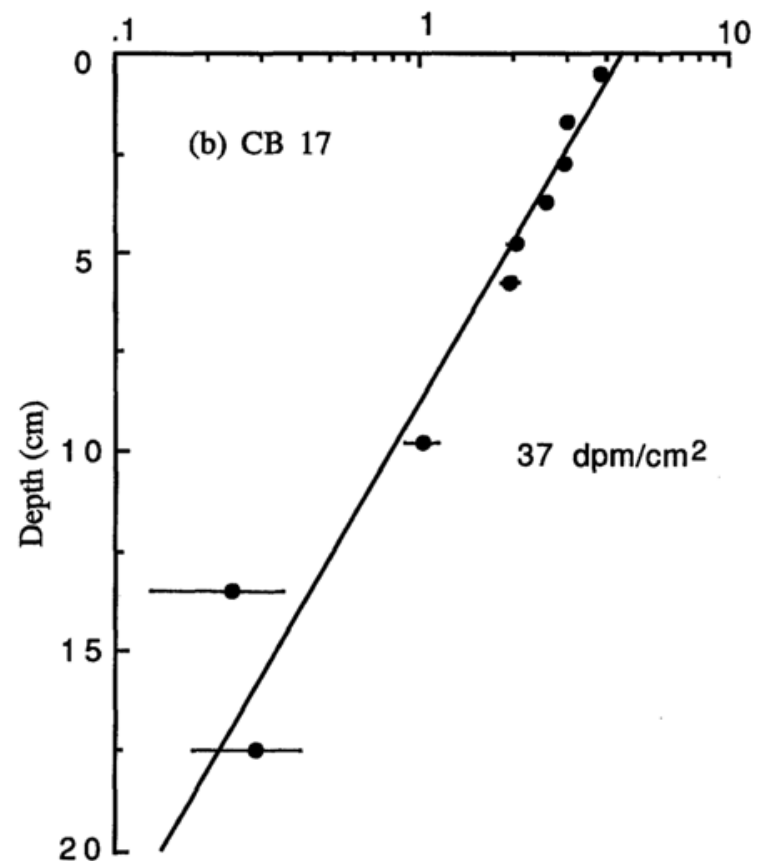

Fig. 3. Vertical profiles of excess ${ }^{210} \mathrm{~Pb}$ in the sediments. (a) at Station $C B$ 7-2 in the Okinawa Trough. (b) at Station $C B 17$ in the continental shelf zone in the East China Sea.

served the ${ }^{230} \mathrm{Th}_{\mathrm{Ex}}$ flux at $640 \mathrm{~m}$ to be 1.24 $\mathrm{dpm} / \mathrm{cm}^{2} / \mathrm{kyr}$, which is $75 \%$ of ${ }^{230} \mathrm{Th}$ produced in the overlying water column (Table 5). This percentage is typical of those observed in the oligotrophic open ocean. It seems likely that the removal of ${ }^{210} \mathrm{~Pb}$ from the overlying water column is inefficient due to the smaller total mass flux in the trough region. Thus, a substantial 
part of ${ }^{210} \mathrm{~Pb}$ derived from the atmosphere is considered to be carried away with the Kuroshio current from the East China Sea, as found in the Japan Sea (Nozaki et al., 1973).

The flux of ${ }^{210} \mathrm{~Pb}$ during its sinking from 640 $\mathrm{m}$ to $1390 \mathrm{~m}$ increased by $1.7 \mathrm{dpm} / \mathrm{cm}^{2} / \mathrm{yr}$, which was 4 times the amount of ${ }^{210} \mathrm{~Pb}$ produced from ${ }^{226} \mathrm{Ra}$ in the water column calculated from the data of Nozaki et al. (1990a). On the other hand, the accumulation rate of ${ }^{210} \mathrm{~Pb}$ to the sediment of $\mathrm{CB} 7-2$ is observed to be 2.4 $\mathrm{dpm} / \mathrm{cm}^{2} / \mathrm{yr}$ (Fig. 3-a), being nearly equal to the flux observed at $1920 \mathrm{~m}$. Although the duration of the sediment-trap deployment was only 2 weeks, the coincidence of these two values indicates that this observation may not be an extreme case. Thus, the addition of laterally transported ${ }^{210} \mathrm{~Pb}$-bearing particles is required to explain the large increase in the ${ }^{210} \mathrm{~Pb}$ flux during $750 \mathrm{~m}$ of sinking.

Lead-210 is effectively scavenged from sea water at the margin of the ocean (Bacon et al., 1976; Nozaki et al., 1980; Spencer et al., 1881; Cochran et al., 1983; etc.). It has been also noted by Bacon et al. (1988) that a strong ${ }^{210} \mathrm{~Pb}$ concentration gradient exists in the shelf-edge zone. In the East China Sea, the concentrations of ${ }^{210} \mathrm{~Pb}$ in surface water deceased by a factor of 5-10 from the Kuroshio to the shelf (Nozaki et al., $1990 \mathrm{~b}$ ), while the concentrations of ${ }^{226} \mathrm{Ra}$ increased by a factor of two (Nozaki et al., 1989). This indicates that ${ }^{210} \mathrm{~Pb}$ is actively removed by the settling particles in the shelf water relative to the Kuroshio water. Fig. 3-b shows that the "apparent" sedimentation rate at Station CB 17 is $0.18 \mathrm{~cm} / \mathrm{yr}$, which also indicates the accumulation rate of ${ }^{210} \mathrm{~Pb}$ is $1.2 \mathrm{dpm} / \mathrm{cm}^{2} / \mathrm{yr}$. This value corresponds to $70 \%$ of the atmospheric influx of ${ }^{210} \mathrm{~Pb}$. As the shelf sediment was mostly compos- ed of sandy deposits (Chin, 1979), ${ }^{210} \mathrm{~Pb}$ removed by settling particles in the shelf water may not be incorporated into the shelf sediments. It is suggested that ${ }^{210} \mathrm{~Pb}$-bearing particles are laterally transported by the tidal current from the shelf region, via the near bottom layer, to the deep trough, and therefore, the Okinawa Trough acts as a large sink of particles containing ${ }^{210} \mathrm{~Pb}$ and other reactive metals. Similar cases are found in the Santa Barbara Basin (Moore et al., 1981) and in the Panama and Guatemala Basin (Anderson et al., 1983b).

The ${ }^{210} \mathrm{~Pb} /{ }^{232} \mathrm{Th}$ and ${ }^{230} \mathrm{Th} /{ }^{232} \mathrm{Th}$ activity ratios in the settling particles (Table 2) were significantly higher than those in the shelf and slope sediments (Table 4). This implies that the particles collected in the sediment trap did not come directly from the bottom sediments as resuspended particles, but that ${ }^{210} \mathrm{~Pb}$ and ${ }^{230} \mathrm{Th}$ were incorporated into the particles during the lateral transport.

The ${ }^{210} \mathrm{Po} /{ }^{210} \mathrm{~Pb}$ activity ratio in the settling particles

The concentrations of ${ }^{210} \mathrm{Po}$ and the ${ }^{210} \mathrm{Po} /{ }^{210} \mathrm{~Pb}$ activity ratio in the settling particles are shown in Tables 2 and 3. Although the concentrations and fluxes of ${ }^{210} \mathrm{Po}$ increased with depth, the ${ }^{210} \mathrm{Po} /{ }^{210} \mathrm{~Pb}$ activity ratio was constant and about unity. This is different from the results observed in the Sargasso Sea (Spencer et al., 1978), the northern North Pacific (Tsunogai et al., 1982), the East Pacific and the Antarctic Ocean (Harada and Tsunogai, 1986a) where the ratios were greater than unity, reflecting the greater reactivity or the shorter residence time of ${ }^{210} \mathrm{Po}$ in sea water. We have shown above that the ${ }^{210} \mathrm{~Pb}$ flux increased 10 times while sinking from 640 to $1390 \mathrm{~m}$. The flux of ${ }^{210} \mathrm{Po}$ also increased.

Table 2. Activity ratios of radionuclides in the settling particles

\begin{tabular}{rcccccc}
\hline $\begin{array}{c}\text { Depth } \\
(\mathrm{m})\end{array}$ & ${ }^{234} \mathrm{U} /{ }^{238} \mathrm{U}$ & ${ }^{238} \mathrm{U} /{ }^{232} \mathrm{Th}$ & ${ }^{230} \mathrm{Th} /{ }^{232} \mathrm{Th}$ & ${ }^{228} \mathrm{Th} /{ }^{232} \mathrm{Th}$ & ${ }^{210} \mathrm{~Pb} /{ }^{232} \mathrm{Th}$ & ${ }^{210} \mathrm{Po} /{ }^{210} \mathrm{~Pb}$ \\
\hline 640 & $1.08 \pm 0.08$ & $1.06 \pm 0.06$ & $0.90 \pm 0.05$ & $5.77 \pm 0.24$ & $70.5 \pm 4.5$ & $1.05 \pm 0.05$ \\
1390 & $0.90 \pm 0.04$ & $0.77 \pm 0.03$ & $0.97 \pm 0.03$ & $9.17 \pm 0.20$ & $158 \pm 4$ & $0.97 \pm 0.02$ \\
1920 & $0.94 \pm 0.05$ & $0.78 \pm 0.03$ & $1.18 \pm 0.03$ & $10.5 \pm 0.2$ & $214 \pm 7$ & $0.99 \pm 0.03$ \\
\hline
\end{tabular}


Table 3. Concentrations of radionuclides in the surface sediments

\begin{tabular}{|c|c|c|c|c|c|}
\hline \multirow{2}{*}{$\begin{array}{l}\text { Code } \\
\text { and } \\
\text { location }\end{array}$} & \multirow{2}{*}{$\begin{array}{l}\text { Combustion } \\
\text { loss } \\
(\%)\end{array}$} & \multicolumn{4}{|c|}{ Concentration $(\mathrm{dpm} / \mathrm{g})$} \\
\hline & & ${ }^{238} \mathrm{U}$ & ${ }^{232} \mathrm{Th}$ & ${ }^{230} \mathrm{Th}$ & ${ }^{210} \mathrm{~Pb}$ \\
\hline CB 17 & $\left(28^{\circ} 30^{\prime} \mathrm{N}, 123^{\circ} 30^{\prime} \mathrm{E}\right.$, & $65 \mathrm{~m})$ & & & \\
\hline & 3.86 & $0.953 \pm 0.035$ & $2.44 \pm 0.10$ & $1.27 \pm 0.05$ & $4.67 \pm 0.20$ \\
\hline CB 15 & $\left(27^{\circ} 31^{\prime} \mathrm{N}, 123^{\circ} 51^{\prime} \mathrm{E}\right.$, & $97 \mathrm{~m})$ & & & \\
\hline & 0.73 & $0.859 \pm 0.038$ & $1.85 \pm 0.07$ & $1.06 \pm 0.05$ & $8.43 \pm 0.22$ \\
\hline CB 14 & $\left(27^{\circ} 13^{\prime} \mathrm{N}, 124^{\circ} 34^{\prime} \mathrm{E}\right.$, & $110 \mathrm{~m})$ & & & \\
\hline CB 13 & $\begin{array}{c}1.12 \\
\left(26^{\circ} 45^{\prime} \mathrm{N}, 124^{\circ} 32^{\prime} \mathrm{E},\right.\end{array}$ & $\begin{array}{l}1.73 \pm 0.07 \\
128 \mathrm{~m})\end{array}$ & $2.14 \pm 0.11$ & $1.41 \pm 0.06$ & $9.64 \pm 0.19$ \\
\hline CB 12 & $\begin{aligned} & 1.22 \\
\left(25^{\circ} 47^{\prime} \mathrm{N},\right. & 124^{\circ} 53^{\prime} \mathrm{E}\end{aligned}$ & $\begin{array}{c}1.08 \pm 0.04 \\
1330 \mathrm{~m})\end{array}$ & $1.51 \pm 0.07$ & $0.978 \pm 0.044$ & $6.95 \pm 0.15$ \\
\hline CB 7-2 & $\begin{array}{c}1.40 \\
\left(25^{\circ} 47^{\prime} \mathrm{N}, 125^{\circ} 22^{\prime} \mathrm{E},\right.\end{array}$ & $\begin{array}{c}1.13 \pm 0.04 \\
2160 \mathrm{~m})\end{array}$ & $2.43 \pm 0.07$ & $1.41 \pm 0.07$ & $11.2 \pm 0.3$ \\
\hline & 4.16 & $1.44 \pm 0.05$ & $3.15 \pm 0.13$ & $3.41 \pm 0.14$ & $36.2 \pm 0.8$ \\
\hline
\end{tabular}

All errors are of $1 \sigma$ counting statistics.

The fact that the ${ }^{210} \mathrm{Po} /{ }^{210} \mathrm{~Pb}$ activity ratio in the setting particles was unity means that the particles which were laterally transported from the shelf region should have the ratio of about unity. If the initial ${ }^{210} \mathrm{Po} /{ }^{210} \mathrm{~Pb}$ ratio is significantly larger than unity, the particles must be transported from the shelf zone after spending more than one year there.

\section{The fluxes of ${ }^{228} \mathrm{Th}_{E X}$ and ${ }^{230} \mathrm{Th}_{E X}$}

Thorium-228 (half-life, $1.91 \mathrm{yr}$ ) and ${ }^{230} \mathrm{Th}$ (half-life, $75200 \mathrm{yr}$ ) are produced from the radioactive decay of ${ }^{228} \mathrm{Ra}$ and ${ }^{234} \mathrm{U}$ of their direct parent nuclides, respectively. The sources of those nuclides are atmospheric and riverine lithogenic particles in a nearly equilibrium state with their parent nuclides and radiogenic particles from ${ }^{228} \mathrm{Ra}$ and ${ }^{234} \mathrm{U}$ dissolved in sea water. It is assumed that the ${ }^{234} \mathrm{U} /{ }^{230} \mathrm{Th}$ detrital ratio is equal to the ratio measured in the surface sediment. It is also assumed that ${ }^{228} \mathrm{Th}$ and ${ }^{230} \mathrm{Th}$ in lithogenic particles are in equilibrium with ${ }^{232} \mathrm{Th}$, which is a grandparent of ${ }^{228} \mathrm{Th}$, and ${ }^{234} \mathrm{U}$, respectively. We calculate the unsupported ${ }^{228} \mathrm{Th}$ (designated ${ }^{228} \mathrm{Th}_{\mathrm{Ex}}$ ) and ${ }^{230} \mathrm{Th}$ (designated ${ }^{230} \mathrm{Th}_{\mathrm{EX}}$ ) as follows:

$$
\begin{aligned}
{ }^{228} \mathrm{Th}_{\mathrm{EX}}= & { }^{228} \mathrm{Th}_{\mathrm{PR}}-{ }^{232} \mathrm{Th}_{\mathrm{PR}}, \\
& { }^{230} \mathrm{Th}_{\mathrm{EX}}={ }^{230} \mathrm{Th}_{\mathrm{PR}}-\left({ }^{234} \mathrm{Th} / \mathrm{h}_{\mathrm{PR}},\right.
\end{aligned}
$$

Table 4. Activity ratios of radionuclides in the surface sediments

\begin{tabular}{ccccc}
\hline $\begin{array}{c}\text { Station } \\
\text { code }\end{array}$ & ${ }^{234} \mathrm{U} /{ }^{238} \mathrm{U}$ & ${ }^{238} \mathrm{U} /{ }^{232} \mathrm{Th}$ & ${ }^{230} \mathrm{Th} /{ }^{232} \mathrm{Th}$ & ${ }^{210} \mathrm{~Pb} /{ }^{232} \mathrm{Th}$ \\
\hline CB 17 & $1.03 \pm 0.02$ & $0.39 \pm 0.02$ & $0.52 \pm 0.02$ & $1.91 \pm 0.11$ \\
CB 15 & $1.05 \pm 0.02$ & $0.46 \pm 0.03$ & $0.57 \pm 0.02$ & $4.56 \pm 0.21$ \\
CB 14 & $1.01 \pm 0.02$ & $0.81 \pm 0.05$ & $0.66 \pm 0.04$ & $4.50 \pm 0.25$ \\
CB 13 & $1.01 \pm 0.02$ & $0.72 \pm 0.04$ & $0.65 \pm 0.04$ & $4.60 \pm 0.23$ \\
CB 12 & $1.01 \pm 0.02$ & $0.47 \pm 0.02$ & $0.58 \pm 0.03$ & $4.61 \pm 0.18$ \\
CB 7-2 & $0.95 \pm 0.03$ & $0.46 \pm 0.02$ & $1.08 \pm 0.06$ & $11.5 \pm 0.5$ \\
\hline
\end{tabular}

where the subscripts PR and SED refer to settling particles and sediment, respectively, and the symbols of nuclides indicate their concentrations in radioactivity. The ${ }^{234} \mathrm{U} /{ }^{232} \mathrm{Th}$ activity ratio in the surface sediment used is $0.44 \pm 0.02$, which is observed at Station CB 7-2 (Table 4).

The calculated results (Table 5) show a steep increase in the fluxes of ${ }^{228} \mathrm{Th}_{\mathrm{Ex}}$ and ${ }^{230} \mathrm{Th}_{\mathrm{Ex}}$ with depth. The ${ }^{230} \mathrm{Th}_{\mathrm{EX}}$ fluxes at $1390 \mathrm{~m}$ and $1920 \mathrm{~m}$ depth are greater than the amounts produced in the overlying water. The increase in the ${ }^{230} \mathrm{Th}_{\mathrm{EX}}$ flux from $640 \mathrm{~m}$ to $1390 \mathrm{~m}$ is $5.1 \mathrm{dpm} / \mathrm{cm}^{2} / \mathrm{kyr}$, which is almost 3 times greater than its production in the water column, $2.0 \mathrm{dpm} / \mathrm{cm}^{2} / \mathrm{kyr}$. The $\left({ }^{228} \mathrm{Th} /{ }^{230} \mathrm{Th}\right)_{\mathrm{Ex}}$ ratio in the particles settling through this water column has increased from 10.4 to 15.6 (Table 5), although the ratio usually decreased with depth in the open ocean (Taguchi et al., 1989; Tsunogai et al., 1990). This trend is 
Table 5. Concentrations and particulate fluxes of unsupported ${ }^{230} \mathrm{Th}$ and ${ }^{228} \mathrm{Th}$

\begin{tabular}{|c|c|c|c|c|c|c|}
\hline \multirow{2}{*}{$\begin{array}{l}\text { Depth } \\
\text { (m) }\end{array}$} & \multicolumn{3}{|c|}{${ }^{230} \mathrm{Th}$ ex } & \multicolumn{2}{|c|}{${ }^{228} \mathrm{Th}$ ex } & \multirow{2}{*}{$\begin{array}{l}\left({ }^{228} \mathrm{Th} /{ }^{230} \mathrm{Th}\right)_{\mathrm{ex}} \\
\text { Activity ratio }\end{array}$} \\
\hline & $\begin{array}{l}\text { Concentration } \\
(\mathrm{dpm} / \mathrm{g})\end{array}$ & $\underset{\left(\mathrm{dmp} / \mathrm{cm}^{2} / \mathrm{kyr}\right)}{\text { Flux }}$ & Flux/Production* & $\begin{array}{l}\text { Concentration } \\
(\mathrm{dmp} / \mathrm{g})\end{array}$ & $\underset{\left(\mathrm{dpm} / \mathrm{cm}^{2} / \mathrm{kyr}\right)}{\text { Flux }}$ & \\
\hline 640 & $0.817 \pm 0.082$ & 1.24 & 0.75 & $8.52 \pm 0.21$ & 13.0 & 10.4 \\
\hline 1390 & $1.08 \pm 0.06$ & 6.30 & 1.74 & $16.8 \pm 0.2$ & 97.9 & 15.6 \\
\hline 1920 & $1.52 \pm 0.06$ & 10.3 & 2.06 & $19.5 \pm 0.2$ & 132 & 12.8 \\
\hline
\end{tabular}

*Amount produced by the decay of uranium in the overlying water, $F_{\text {prod. }}=2.6 \mathrm{D}$ (water cloumn depth in $\mathrm{km}$ ).
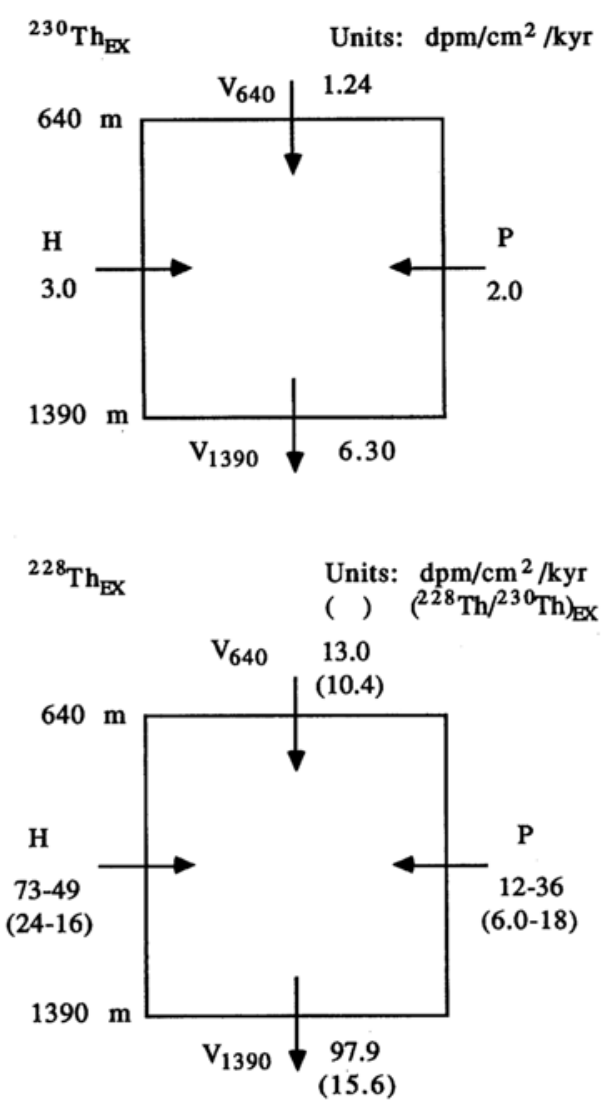

Fig. 4. The budget of ${ }^{230}{ }^{T} h_{E X}$ and ${ }^{228}{ }^{2} h_{E X}$ in the water column between $640 \mathrm{~m}$ and $1390 \mathrm{~m}$ depth.

the same as that of ${ }^{210} \mathrm{~Pb}$ which was shown above. This fact also means that the particles, which are removed in the continental shelf zone, are transported into the deep trough, because the concentration of ${ }^{228} \mathrm{Ra}$ in the shelf water is usually high due to its release from the sediments (Kaufman et al., 1981; Nozaki et al., 1989, 1990b).
Figure 4 shows the budget of ${ }^{230} \mathrm{Th}_{\mathrm{Ex}}$ and ${ }^{228} \mathrm{Th}_{\mathrm{EX}}$ in the water column between $640 \mathrm{~m}$ and $1390 \mathrm{~m}$ depth. In the steady state, the balance of ${ }^{230} \mathrm{Th}_{\mathrm{EX}}$ is expressed as follows:

$$
\mathrm{V}_{640}+\mathrm{P}+\mathrm{H}=\mathrm{V}_{1390} \text {, }
$$

where $\mathrm{V}_{640}$ and $\mathrm{V}_{1390}$ are the vertical fluxes of ${ }^{230} \mathrm{Th}_{\text {EX }}$ at $640 \mathrm{~m}$ and $1390 \mathrm{~m}$ depth, respectively, $\mathrm{P}$ is the production rate of ${ }^{230} \mathrm{Th}$ from ${ }^{234} \mathrm{U}$ in the water column of $750 \mathrm{~m}$ depth and $\mathrm{H}$ is the lateral flux of ${ }^{230} \mathrm{Th}_{\mathrm{Ex}}$. The units are $\mathrm{dpm} / \mathrm{cm}^{2} / \mathrm{kyr}$ for all the terms. The lateral flux of ${ }^{230} \mathrm{Th}_{\mathrm{Ex}}$ into this water column is calculated to be 3.0 $\mathrm{dpm} / \mathrm{cm}^{2} / \mathrm{kyr}$ as shown in Fig. 4.

For the concentration of ${ }^{228} \mathrm{Ra}$ in the Okinawa Trough deep water, we use values 2 $\mathrm{dpm} / 10^{3} 1$ as a lower limit and $5 \mathrm{dpm} / 10^{3} 1$ as an upper limit, since we didn't measure it in the trough water. The lower limit is based on the assumption that the water of the Philippine Sea of $1000 \mathrm{~m}$ depth is the only source of the trough deep water, which contains $2 \mathrm{dpm} / 10^{3} \mathrm{l}$ of ${ }^{228} \mathrm{Th}$ (Taguchi, 1989). The upper limit is estimated from the assumption that all the ${ }^{228} \mathrm{Ra}$ from the trough bottom sediment of the Okinawa Trough, which is the same as that of the Japan Sea, decays in the trough deep water (below $\mathbf{5 0 0}$ $\mathrm{m}$ ) after mixing thoroughly in the deep water. In the steady state, the diffusive flux of ${ }^{228} \mathrm{Ra}$ from the bottom sediment in the Japan Sea is given by:

$$
\mathrm{F}=\left\{\lambda \times \mathrm{A}_{\mathrm{D}}+\left(\mathrm{A}_{\mathrm{D}}-\mathrm{A}_{\mathrm{S}}\right) / \tau\right\} \times \mathrm{L},
$$

where $\mathrm{F}\left(\mathrm{dpm} / \mathrm{cm}^{2} / \mathrm{yr}\right)$ is the ${ }^{228} \mathrm{Ra}$ flux, $\lambda\left(\mathrm{yr}^{-1}\right)$ is the decay constant of ${ }^{228} \mathrm{Ra}, \tau(\mathrm{yr})$ is the mean residence time of the Japan Sea deep water, and 
$L$ is the mean thickness of the deep reservoir. The ${ }^{228} \mathrm{Ra}$ flux from the bottom sediment of the Japan Sea turns out to be $0.078 \mathrm{dpm} / \mathrm{cm}^{2} / \mathrm{yr}$ by using the following values: $A_{D}=7.7 \mathrm{dpm} / 10^{3} \mathrm{l}$, which is the mean concentration of ${ }^{228} \mathrm{Ra}$ in the deep reservoir below $500 \mathrm{~m} ; A_{S}=50 \mathrm{dpm} / 10^{3} \mathrm{l}$, which is the mean concentration of ${ }^{228} \mathrm{Ra}$ in the surface reservoir above $500 \mathrm{~m}$ (Okubo, 1980); $\mathrm{L}=1000 \mathrm{~m}$, which is based on the mean total depth of the Japan Sea $(1500 \mathrm{~m}$; Harada and Tsunogai, 1986a); and $\tau=300 \mathrm{yr}$, which is estimated by Gamo and Horibe (1983) and Harada and Tsunogai (1986a). From this flux and the mean total depth of the trough area deeper than $1000 \mathrm{~m}(1600 \mathrm{~m})$, the concentration of ${ }^{228} \mathrm{Ra}$ in the Okinawa Trough deep water is calculated to be $6 \mathrm{dpm} / 10^{3}$. Thus, if we can assume that the residence time of $\mathrm{Th}$ isotopes in the Okinawa Trough deep water is equal to that in the Japan Sea deep water (10 years; Nozaki and Yamada, 1987), the in situ production rate of ${ }^{228} \mathrm{Th}$ is $12 \sim 36 \mathrm{dpm} / \mathrm{cm}^{2} / \mathrm{kyr}$. Thus, the obtained lateral flux ranges $49 \sim 73 \mathrm{dpm} / \mathrm{cm}^{2} / \mathrm{kyr}$, indicating that the $\left({ }^{228} \mathrm{Th} /{ }^{230} \mathrm{Th}\right)_{\mathrm{Ex}}$ activity ratio is $16 \sim 24$ in the particles laterally transported from the shelf.

Since ${ }^{228} \mathrm{Th}$ in the shelf zone in the New York Bight is quickly removed after a residence time of less than 10 days (Kaufman et al., 1981), we assume that all ${ }^{228} \mathrm{Th}$ produced in the East China Sea is at once removed to sediments. The concentration of ${ }^{228} \mathrm{Ra}$ is reported to be $470 \mathrm{dpm} / 10^{3} 1$ (Nozaki et al., 1989). The flux of ${ }^{228} \mathrm{Th}\left(\mathrm{F}_{228}\right.$, $\mathrm{dpm} / \mathrm{cm}^{2} / \mathrm{kyr}$ ) at $\mathrm{Z} \mathrm{m}$ depth is given by:

$$
\mathrm{F}_{228}=470 \times 10^{-4} \times \mathrm{Z} \times \lambda_{228},
$$

where $\lambda_{228}$ is the decay constant of ${ }^{228} \mathrm{Th}$ $\left(3.63 \times 10^{2} \mathrm{kyr}^{-1}\right)$.

From the average salinity of the shelf water of $31 \%$, the ${ }^{234} \mathrm{U}$ concentration of the shelf water is calculated to be $2.5 \mathrm{dpm} / 1(0.0708 \times \mathrm{S} \% \times 1.14$; $\mathrm{Ku}$ et al., 1975). Similarly with ${ }^{228} \mathrm{Th}$, the flux of ${ }^{230} \mathrm{Th}\left(\mathrm{F}_{230}, \mathrm{dpm} / \mathrm{cm}^{2} / \mathrm{kyr}\right)$ at $\mathrm{Z}$ m depth can be assumed to be:

$$
\mathrm{F}_{230}=2.5 \times 10^{-1} \times \mathrm{Z} \times \lambda_{230},
$$

where $\lambda_{230}$ is the decay constant of ${ }^{230} \mathrm{Th}$ $\left(9.22 \times 10^{-3} \mathrm{kyr}^{-1}\right)$.

Therefore, the ${ }^{228} \mathrm{Th} /{ }^{230} \mathrm{Th}$ activity ratio in the settling particles formed in the shelf zone at any given depth turns out to be:

$$
\begin{aligned}
\left({ }^{228} \mathrm{Th} /{ }^{230} \mathrm{Th}\right)_{\mathrm{PR}} & =\mathrm{F}_{228} / \mathrm{F}_{230} \\
& =7400,
\end{aligned}
$$

This initial ratio is much larger than the activity ratio of $16 \sim 23$ obtained above. Since both ${ }^{230} \mathrm{Th}$ and ${ }^{228} \mathrm{Th}$ transported laterally in the deep trough are mainly produced in the shelf zone, the difference in the activity ratio should be due to the radioactive decay during the lateral transport. Thus, the necessary time for the decrease in the ratio from 7400 to $16 \sim 24$ turns out to be nearly 16 years, because it is 9 times the half-life of ${ }^{228} \mathrm{Th}$ of 1.91 years. It is suggested that the particles laterally transported from the shelf zone were neither virgin particles nor older particles, with an average age of 16 years.

\section{Summary AND Conclusions}

(1) About half of the settling particles in the deep Okinawa Trough consists of lithogenic particles. This is based on the concentration of ${ }^{232} \mathrm{Th}$ in the settling particles, which is relatively constant with depth.

(2) The increments of ${ }^{210} \mathrm{~Pb},{ }^{228} \mathrm{Th}_{\mathrm{Ex}}$ and ${ }^{230} \mathrm{Th}_{\mathrm{Ex}}$ fluxes while they are sinking through the water column of $640-1390 \mathrm{~m}$, were much higher than those expected from the vertical profiles of these nuclides and their parents in sea water. Particularly, the increases in the fluxes of ${ }^{210} \mathrm{~Pb}$ and ${ }^{228} \mathrm{Th}_{\mathrm{EX}}$ originating intensively in the shelf region were larger than ${ }^{230} \mathrm{Th}_{\mathrm{Ex}}$ produced evenly in sea water.

(3) The ${ }^{210} \mathrm{Po} /{ }^{210} \mathrm{~Pb}$ activity ratio in the settling particles was about unity. The $\left({ }^{228} \mathrm{Th} /{ }^{230} \mathrm{Th}\right)$ Ex activity ratio caused by particles transported from the continental shelf was $16 \sim 24$. This value is about 350 times smaller than the activity ratio calculated from the production rate of these nuclides in the shelf water.

These results indicate that the particles are laterally transported from the continental shelf in the East China Sea to the Okinawa Trough. 
The concentrations and fluxes of radiogenic nuclides such as ${ }^{210} \mathrm{~Pb},{ }^{228} \mathrm{Th}_{\mathrm{Ex}}$, and ${ }^{230} \mathrm{Th}_{\mathrm{EX}}$ increased with depth and their fluxes were larger than those calculated from the inventories of the nuclides and their respective parents in the water column above the sampling depth. About 70\% of ${ }^{210} \mathrm{~Pb}, 60 \%$ of ${ }^{228} \mathrm{Th}_{\mathrm{EX}}$, and $50 \%$ of ${ }^{230} \mathrm{Th}_{\mathrm{EX}}$ fluxes observed at $1390 \mathrm{~m}$ depth in the Okinawa Trough originated in the continental shelf zone. These particles were neither fresh particles nor older particles such as resuspended particles, and the particles removed first from the shelf region may be transported laterally on the time scale of about 16 years.

Acknowledgments-We would like to thank Prof. H. Sakai, other scientists, officers and crew aboard the KH-87-2 cruises of the R/V Hakuho-Maru. Helpful discussions and assistance with the sampling by Dr. S. Noriki, are gratefully acknowledged. Also, thanks are extended to Mr. S. Nagao, Ms. C. Saito, Mr. Y. Abe, and the members of the Laboratory of Analytical Chemistry, Hokkaido University for their cooperation during the sampling and chemical analyses. Finally we would like to thank Prof. W. C. Burnett for reading this manuscript and for valuable comments.

\section{REFERENCES}

Aller, R. C. and Cochran, J. K. (1976) ${ }^{234}$ Th/238U disequilibrium in near-shore sediment: particle reworking and diagenetic time scale. Earth Planet. Sci. Lett. 29, 37-50.

Anderson, R. F., Bacon, M. P. and Brewer, P. C. (1983a) Removal of ${ }^{230} \mathrm{Th}$ and ${ }^{231} \mathrm{~Pa}$ from the open ocean. Earth Planet. Sci. Lett. 62, 7-23.

Anderson, R. F., Bacon, M. P. and Brewer, P. C. (1983b) Removal of ${ }^{230} \mathrm{Th}$ and ${ }^{231} \mathrm{~Pa}$ at ocean margins. Earth Planet. Sci. Lett. 66, 73-90.

Bacon, M. P., Belastock, R. A., Tecotzky, M., Turekian, K. K. and Spencer, D. W. (1988) Lead210 and polonium-210 in ocean water profiles of the continental shelf and slope south of New England. Continental Shelf Res. 8, 841-853.

Bacon, M. P., Spencer, D. W. and Brewer, P. G. (1976) ${ }^{210} \mathrm{~Pb} /{ }^{226} \mathrm{Ra}$ and ${ }^{210} \mathrm{Po} /{ }^{210} \mathrm{~Pb}$ disequilibria in seawater and particulate matter. Earth Planet. Sci. Lett. 32, 277-296.

Biscaye, T. G., Anderson, R. F. and Deck, B. L. (1988) Fluxes of particles and constituents to the eastern United States continental slope and rise: SEEP-I. Continental Shelf Res. 8, 855-904.
Brewer, P. G., Nozaki, Y., Spencer, D. W. and Fleer, A. P. (1980) Sediment trap experiments in the deep North Atlantic: isotopic and elemental fluxes. $J$. Mar. Res. 38, 703-728.

Chin, Y.-S. (1979) A study on sediment and mineral compositions of the sea floor of the East China Sea. Oceanic Selections 2, 93-120.

Cochran, J. K., Bacon, M. P., Krishnaswami, S. and Turekian, K. K. (1983) ${ }^{210} \mathrm{Po}$ and ${ }^{210} \mathrm{~Pb}$ distributions in the central and eastern Indian Ocean. Earth Planet. Sci. Lett. 65, 433-452.

Craig, H., Krishnaswami, S. and Somayajulu, B. L. K. (1973) ${ }^{210} \mathrm{~Pb}-{ }^{226} \mathrm{Ra}$ : Radioactive disequilibrium in the deep sea. Earth Planet. Sci. Lett. 17, 295305.

Gamo, T. and Horibe, Y. (1983) Abyssal circulation in the Japan Sea. J. Oceanogr. Soc. Jpn. 39, 220230.

Harada, K. and Tsunogai, S. (1985) A practical method for the simultaneous determinations of 234 $\mathrm{Th},{ }^{226} \mathrm{Ra},{ }^{210} \mathrm{~Pb}$ and ${ }^{210} \mathrm{Po}$ in sea water. $J$. Oceanogr. Soc. Jpn. 41, 98-104.

Harada, K. and Tsunogai, S. (1986a) Fluxes of ${ }^{234} \mathrm{Th}$, ${ }^{210} \mathrm{Po}$ and ${ }^{210} \mathrm{~Pb}$ determined by sediment trap experiments in pelagic oceans. J. Oceanogr. Soc. Jpn. 43, 192-200.

Harada, K. and Tsunogai, S. (1986b) ${ }^{226} \mathrm{Ra}$ in the Japan Sea and the residence time of the Japan Sea water. Earth Planet. Sci. Lett. 77, 236-244.

Honjo, S., Manganini, S. J. and Cole, J. J. (1982) Sedimentation of biogenic matter in the deep ocean. Deep-Sea Res. 29, 609-625.

Kaufman, A., Li, Y.-H. and Turekian, K. K. (1981) The removal rates of ${ }^{234} \mathrm{Th}$ and ${ }^{228} \mathrm{Th}$ from waters of the New York Bight. Earth Planet. Sci. Lett. 54, 385-392.

Ku, L.-H., Knauss, K. G. and Mathieu, G. G. (1975) Uranium in open ocean: concentration and isotopic composition. Deep-Sea Res. 24, 1005-1117.

Li, Y.-H., Feely, H. W. and Toggweiler, J. R. (1980) ${ }^{228} \mathrm{Ra}$ and ${ }^{228} \mathrm{Th}$ concentrations in GEOSECS Atlantic surface waters. Deep-Sea Res. 27, 545-555.

Matsumoto, E. (1975) Th-234/U-238 disequilibrium in the surface layer of the ocean. Geochim. Cosmochim. Acta 39, 205-212.

Minagawa, M. and Tsunogai, S. (1980) Removal of 234 Th from a costal Sea: Funka Bay, Japan. Earth Planet. Sci. Lett. 47, 51-64.

Moore, W. S. and Sackett, W. M. (1964) Uranium and thorium series in equilibium in seawater. $J$. Geophys. Res. 69, 5401-5405.

Moore, W. S., Bruland, K. W. and Michel, J. (1981) Fluxes of uranium and thorium series isotopes in the Santa Barbara Basin. Earth Planet. Sci. Lett. 53, 391-399. 
Noriki, S. and Tsunogai, S. (1986) Particulate fluxes and major components of settling particles from sediment trap experiments in the Pacific-Ocean. Deep-Sea Res. 33, 903-912.

Nozaki, Y. and Yamada, M. (1987) Thorium and protactinum isotope distributions in waters of the Japan Sea. Deep-Sea Res. 34, 1417-1430.

Nozaki, Y., Horibe, Y. and Tsubota, H. (1981) The water column distributions of thorium isotopes in the western North Pacific. Earth Planet. Sci. Lett. 54, 203-216.

Nozaki, Y., Ikuta, N. and Yashima, M. (1990a) Large ${ }^{210} \mathrm{Po}$ deficiencies relative to ${ }^{210} \mathrm{~Pb}$ in the Kuroshio Current of the East China and Philippine Seas. $J$. Geophys. Res. 95, 5321-5329.

Nozaki, Y., Kasemsupaya, V. and Tsubota, H. (1989) Mean residence time of the shelf water in the East China and the Yellow Seas determined by ${ }^{228} \mathrm{Ra} /{ }^{226}$ Ra measurements. Geophys. Res. Lett., 16, 12971300.

Nozaki, Y., Thomson, J. and Turekian, K. K. (1976) The distribution of ${ }^{210} \mathrm{~Pb}$ and ${ }^{210} \mathrm{Po}$ in the surface waters of the Pacific Ocean. Earth Planet. Sci. Lett. 32, 304-312.

Nozaki, Y., Tsunogai, S. and Nishimura, M. (1973) Lead-210 in Japan Sea. J. Oceanogr. Soc. Jpn. 29, 251-256.

Nozaki, Y., Turekian, K. K. and Von Damn, K. (1980) ${ }^{210} \mathrm{~Pb}$ in GEOSECS water profiles from the North Pacific. Earth Planet. Sci. Lett. 49, 393-400. Nozaki, Y., V. Kasemsupaya, H. Tsubota, Yashima, M. and Ikuta, N. (1990b) The comparative geochemical behaviors of ${ }^{210} \mathrm{~Pb},{ }^{210} \mathrm{Po}$ and $\mathrm{Ra}$ isotopes in the surface water of the East China and the Yellow seas. Submitted to Geochim. Cosmochim. Acta.

Okubo, T. (1980) Ra-228 in the Japan Sea. $J$. Oceanogr. Soc. Jpn. 36, 263-268.

Rama, Koide, M. and Goldberg, E. D. (1961) Lead210 in natural water. Science 134, 98-99.

Spencer, D. W., Bacon, M. P. and Brewer, P. G. (1981) Models of the distribution of ${ }^{210} \mathrm{~Pb}$ in a section across the north equatorial Atlantic Ocean. $J$. Mar. Res. 39, 119-138.

Spencer, D. W., Brewer, P. G., Fleer, A., Honjo, S., Kishinaswami, S. and Nozaki, Y. (1978) Chemical fluxes from a sediment trap experiment in the deep Sargasso Sea. J. Mar. Res. 36, 493-521.

Taguchi, K. (1989) Mechanism of removal of chemical substances in the ocean with $\mathrm{Th}$ and $\mathrm{Pa}$ isotopes. Doctoral thesis. Fish. Sci. submitted to
Hokkaido Univ.

Taguchi, K., Harada, K. and Tsunogai, S. (1989) Particulate removal of ${ }^{230} \mathrm{Th}$ and ${ }^{231} \mathrm{~Pa}$ in the biological productive northern North Pacific. Earth Planet. Sci. Lett. 93, 223-232.

Tsunogai, S. and Kusakabe, K. (1982) Migration of manganese in the deep sea sediment. The Dynamic Environment of the Ocean Floor, ed. by K. A. Fanning and F. T. Manheim, Lexington Books, Lexington, 257-273.

Tsunogal, S. and Noriki, S. (1987) Organic matter fluxes and the sites of oxygen consumption in deep water. Deep-Sea Res. 34, 755-767.

Tsunogai, S. and Nozaki, Y. (1971) Lead-210 and polonium-210 in the surface water of the Pacific. Geochem. J. 5, 165-173.

Tsunogai, S. and Yamada, M. (1980) A radiochemically studied sediment core from the Philippine Sea Basin indicating no accumulation during the past few hundred thousand years. Geochem. J. 14, 1926.

Tsunogai, S., Noriki, S., Harada and Tate, K. (1990) Particulate removal of trace metals in the ocean. Geochem. J. 24, 229-243.

Tsunogai, S., Noriki, S., Harada, K., Kurosaki, T., Watanabe, Y. and Maeda, M. (1986) Large but variable particulate flux in the Antarctic Ocean and its significance for the chemistry of the Antarctic water. J. Oceanogr. Soc. Jpn. 42, 83-90.

Tsunogai, S., Shinagawa, T. and Kurata, T. (1985) Deposition of anthropogenic sulfate and $\mathrm{Pb}-210$ in the Western North Pacific area. Geochem. J. 19, 77-90.

Tsunogai, S., Uematsu, M., Noriki, S., Tanaka, N. and Yamada, M. (1982) Sediment trap experiment in the northern North Pacific: Undulation of settling particles. Geochem. J. 16, 129-147.

Turekian, K. K (1977) The fate of metals in the ocean. Geochim. Cosmochim. Acta 41, 1139-1144.

Uematsu, M., Minagawa, M., Arita H. and Tsunogai, S. (1978) Determination of dry weight of total suspended matter in seawater. Bull. Fac. Fish. Hokkaido Univ. 29, 164-172.

Walsh, J. J., Biscaye, P. E. and Csandy, G. T. (1988) The 1983-1984 Shelf Edge Exchange Processes (SEEP)-I experiment: hypotheses and highlights. Continental Shelf Res. 8, 435-456.

Yang, H.-S., Nozaki, Y., Sakai, H. and Masuda, A. (1986) The distribution of ${ }^{230} \mathrm{Th}$ and ${ }^{231} \mathrm{~Pa}$ in the deep-sea surface sediments of Pacific Ocean. Geochim. Cosmochim. Acta 50, 81-89. 